\title{
PENGARUH PENGEMASAN VAKUM TERHADAP PERUBAHAN MIKROBIOLOGI, AKTIFITAS AIR DAN pH PADA IKAN PARI ASAP
}

\author{
Effect Of Vacuum Packaging on Microbiology Change, Water Activity and pH \\ in Smoke Stingray
}

\author{
Andri Nofreeana ${ }^{1)}$, Aloysius Masi ${ }^{1)}$, Ika Meidy Deviarni ${ }^{1)}$ \\ ${ }^{1)}$ Program Studi Teknologi Pengolahan Hasil Perikanan, Politeknik Negeri Pontianak \\ Email : andrinofreeana@gmail.com
}

\begin{abstract}
The traditional process of fumigation is usually done using a smoke house (open system). This condition causes the uncontrolled curing temperature due to the heat produced out so that the fuming temperature is not maximal (under pasteurization temperature). The long-term goal of this research is for traditional smokers to apply the technology of vacuum packaging. Vacuum packaging is applied in the hope that long-lasting stingray smoked fish products are stored and food security is maintained. The direct benefits of applying this vacuum packing will help the processors of stingrays in marketing and storage. The results showed that storage of smoked stingray with vacuum packaging for both treatments showed no significant difference to microbiological treatment, $A w$ and $p H$.
\end{abstract}

Keywords: vacuum packing, smoke stingray, microbiology, water activities, $p H$

\begin{abstract}
ABSTRAK
Proses pengasapan ikan yang dilakukan secara tradisional biasa dilakukan menggunakan rumah asap (sistem terbuka). Keadaan ini menyebabkan suhu pengasapan yang tidak terkontrol karena panas yang dihasilkan keluar sehingga suhu pengasapan tidak maksimal (dibawah suhu pasteurisasi). Tujuan jangka panjang dalam penelitian ini adalah agar para pengolah tradisional ikan pari asap dapat menerapkan teknologi pengemasan vakum. Pengemasan vakum diterapkan dengan harapan agar produk ikan asap pari lebih tahan lama disimpan dan keamanan pangannya lebih terjaga. Manfaat secara langsung penerapan pengemasan vakum ini ini akan membantu para pengolah produk ikan pari asap dalam pemasaran dan penyimpanan. Hasil penelitian menunjukkan bahwa penyimpanan ikan pari asap dengan kemasan vakum untuk kedua perlakuan tidak menunjukkan beda nyata (significant) terhadap perlakuan mikrobiologi, Aw dan $\mathrm{pH}$.
\end{abstract}

Kata Kunci: pengemasan vakum, pari asap, mikrobiologi, aktifitas air, $\mathrm{pH}$

\section{PENDAHULUAN}

Potensi Sumberdaya Perikanan di Kalimantan Barat cukup besar, berdasarkan data statistik di Kementrian Kelautan dan Perikanan (2012) produksi perikanan tangkap di Kalimantan Barat pada tahun 2010 sebesar 92. 280 ton. Ikan merupakan salah satu komoditas yang cepat membusuk, sehingga jika akan akan disimpan diperlukan penanganan tertentu. Beberapa masyarakat pesisir pantai di Kalimantan
Barat mengembangkan potensi sumber daya ikan sebagai ikan asap.

Proses pengasapan ikan secara tradisional, biasa dilakukan menggunakan rumah asap (sistem terbuka). Keadaan ini menyebabkan suhu pengasapan yang tidak terkontrol karena panas yang dihasilkan keluar sehingga suhu pengasapan tidak maksimal (dibawah suhu pasteurisasi). Pada suhu ini, dikhawatirkan beberapa bakteri 
phatogen masih hidup, keadaan ini akan diperparah pada penyimpanan suhu kamar $\left( \pm 30^{\circ} \mathrm{C}\right)$.

Faktor pengemasan dapat mempengaruhi pertumbuhan mikro-organisme seperti kapang/jamur dan bakteri. Pengemasan dengan menggunakan vakum dapat menghambat pertumbuhan bakteri aerob. Suhu dan lamanya pengasapan juga akan mempengaruhi aktifitas air (aw) yang ada pada daging Ikan Pari Asap. Kandungan aw pada Ikan Pari Asap sangat mempengaruhi ketahan Ikan Pari Asap terhadap proses pembusukan, karena bakteri menggunakan Aw untuk pertumbuhannya. Menurut Kusnandar (2010), Aktivitas air (aw) merupakan parameter yang berpengaruh pada stabilitas dan keawetan pangan, laju reaksi kimia, aktivitas enzim dan pertumbuhan mikrobia. Meningkatnya pertumbuhan mikrobia dan Aw, biasanya akan diikuti oleh kenaikan $\mathrm{pH}$ (basa). Menurut Fardiaz (1992), nilai pH merupakan salah satu indikator tingkat kesegaran ikan. Pada proses pembusukan ikan, $\mathrm{pH}$ daging ikan berubah karena proses autolisis dan penyerangan bakteri. Berdasarkan latar belakang diatas penulis ingin mengetahui perubahan mikrobiologi, aktivitas air, dan $\mathrm{pH}$ pada pari asap yang dikemas vakum pada suhu kamar dam suhu $5{ }^{\circ} \mathrm{C}$. Berdasarkan batas ambang beberapa parameter tersebut, kita dapat mengetahui pada hari keberapa Ikan Pari Asap yang dikemas vakum dan disimpan pada suhu yang berbeda tersebut masih aman untuk dikonsumsi.

\section{METODE}

\section{Pengemasan dan penyimpanan ikan pari asap}

Sampel diambil dari unit usaha kecil menegah di desa Sungai Jaga Kabupaten Bengkayang. Sesampainya di Pontianak sampel langsung dikemas menggunakan plastik polyethylene kemudian di vakum. Setelah dikemas disimpan pada suhu kamar $\left( \pm 30^{\circ} \mathrm{C}\right)$ dan suhu dingin $\left( \pm 5^{\circ} \mathrm{C}\right)$.

\section{Bahan dan alat}

Alat yang digunakan antara lain autoclave, cawan petri, tabung reaksi, $\mathrm{pH}$ meter. Sedangkan bahan yang digunakan antara lain : Ikan Pari Asap, media agar PCA (Plates Count Agar), Aquadest, $\mathrm{NaCl}$, Alkohol.

\section{Analisa mikrobiologi (angka lempeng total/ ALT)}

Satu bagian daging ikan pari asap ditimbang secara aseptis dan dihomogenkan dengan 9 bagian larutan $\mathrm{NaCl} 0,85 \%$ selama 1 menit. Sampel homogen diencerkan berturut turut menggunakan larutan $\mathrm{NaCl} 0,85 \%$ (steril) untuk analisa bakteri dan nilai ALT ditentukan dengan metode pour plate. Analisa mikrobiologi dengan uji ALT dilakukan untuk seluruh perlakuan pada penyimpanan hari ke $0,2,4$, 6,8 pada suhu kamar $\left( \pm 30^{\circ} \mathrm{C}\right)$ dan suhu dingin $\left( \pm 5^{\circ} \mathrm{C}\right)$. Hasil pengujian dicatat dan pengujian dilakukan secara duplo.

\section{Analisa aktifitas air bebas (Aw)}

Aktivitas air bebas (aw) diuji mengikuti metode PrimoMartin dkk. (2009), dengan instrumen aktivitas air yang telah dikalibrasi (Rotronic-Hygrolab, USA). Sampel digerus dengan alat penggerus porselin, sampel bubuk dituang dalam wadah sampel yang selanjutnya diletakkan dalam chamber alat dan dimasukkan kedalam alat, ditunggu pembacaan secara otomatis yang hasilnya akan keluar pada display alat. Pengukuran aW dilakukan untuk seluruh perlakuan pada penyimpanan hari ke $0,2,4,6,8$ pada suhu kamar $\left( \pm 30^{\circ}\right.$ C) dan suhu dingin $\left( \pm 5^{\circ} \mathrm{C}\right)$. Hasil pembacaan dicatat dan pengukuran dilakukan secara duplo.

\section{Analisa pH}

Analisa pH dilakukan dengan mengambil satu bagian sampel Ikan Pari Asap yang di homogenkan dengan 9 bagian aquadest menggunakan magnet stirer selama 30 menit. Setelah homogen dilakukan pengukuran $\mathrm{pH}$ dengan $\mathrm{Ph}$ meter. 
Pengukuran $\mathrm{pH}$ dilakukan untuk seluruh perlakuan pada penyimpanan hari ke $0,2,4$, 6,8 pada suhu kamar $\left( \pm 30^{\circ} \mathrm{C}\right)$ dan suhu dingin $\left( \pm 5^{\circ} \mathrm{C}\right)$. Hasil pembacaan dicatat dan pengukuran dilakukan secara triplo.

\section{Analisa statistik}

Analisa yang digunakan dalam penelitian ini menggunakan analisa statistik uji t, yaitu analisa yang bertujuan untuk mengetahui ada tidaknya beda nyata diantara dua perlakuan yang diuji.

\section{HASIL DAN PEMBAHASAN}

\section{Ikan pari asap}

Ikan Pari asap merupakan salah satu olahan hasil perikanan yang masih banyak diminati masyarakat Kalimantan Barat. Proses pengolahan yang dilakukan pada umumnya masih sangat tradisional. Sebagian masyarakat Kalimantan Barat menggunakan rumah asap sebagai tempat untuk memproduksi ikan pari asap. Lokasi rumah pengasapan ini terdapat dibelakang perkarangan rumah yang banyak tanaman kebun dan sangat dekat dengan permukiman penduduk setempat dengan lokasi pengasapan terbuka.

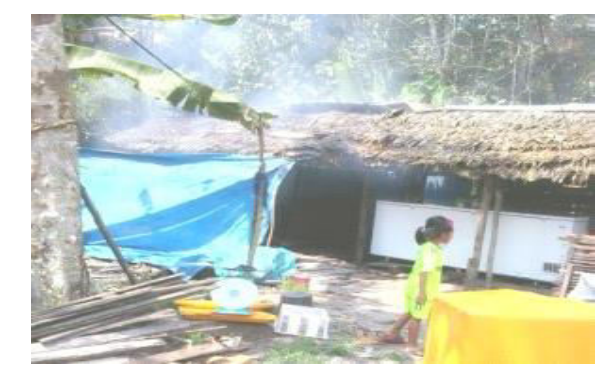

Gambar 1. Rumah asap ikan pari

\section{Proses pengolahan ikan pari asap}

Proses pengolahan ikan pari asap yang ada di daerah Desa sungai Jaga Kabupaten Bengkayang sebagai berikut :

\section{Penyiangan dan pemotongan}

Penyiangan ikan pari dimulai dari pembuangan isi perut dan pembuangan kulit bagian atas. Hal ini dilakukan karena pada bagian isi perut banyak mengandung bakteri pembusuk, selain itu pembuangan kulit ikan pari dibagian atas juga dilakukan karena kulit ikan ini bisa dijual sebagai bahan kerajinan tangan, harga pasarannya sangat tinggi dengan harga Rp.120.000/kg. Setelah itu, ikan dibersihkan dengan air bersih, penyiangan ikan bertujuan untuk membuang kotoran pada perut ikan dengan menggunakan pisau yang tajam.

Setelah dilakukan proses penyiangan selanjutnya dilakukan proses pemotongan. Pemotongan ikan pari ini menggunakan pisau yang tajam dan dialaskan dengan talenan, kemudian ikan pari dipotong dengan ukuran $20 \mathrm{~cm}$ x $5 \mathrm{~cm}$. Pemotongan ini bertujuan untuk menghasilkan ukuran ikan yang seragam. Selain itu juga dengan pemotongan ikan yang seragam akan memudahkan pada saat penyusunan di parapara. Adapun proses penyiangan dan pemotongan ikan pari dapat dilihat pada Gambar 2.

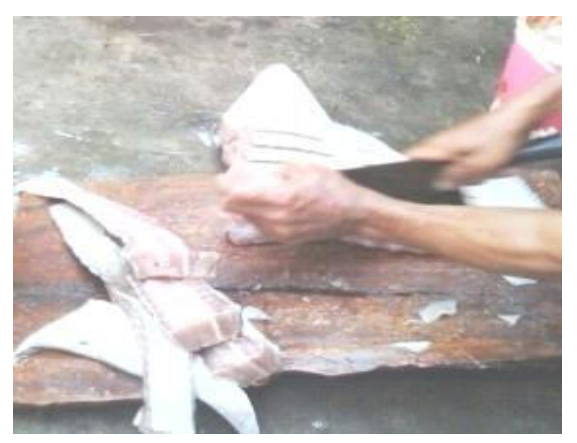

Gambar 2. Pembuangan isi perut dan pemotongan

\section{Pencucian}

Setelah dilakukan proses penyiangan dan pemotongan ikan selanjutnya dilakukan proses pencucian. Pencucian ikan pari ini dilakukan sebanyak 2 kali, yang mana pencucian pertama dicelupkan kedalam fiber box yang berisi air sumur kemudian dicuci dengan cara digosok-gosok agar lendir dan darah yang menempel pada daging ikan hilang, sedangkan untuk pencucian kedua hanya dilakukan pembilasan saja. Tujuan pencucian adalah untuk menghilangkan kotoran yang ada pada ikan pari seperti 
darah dan lendir. Pencucian ikan dapat dilihat pada Gambar 3 dibawah ini.

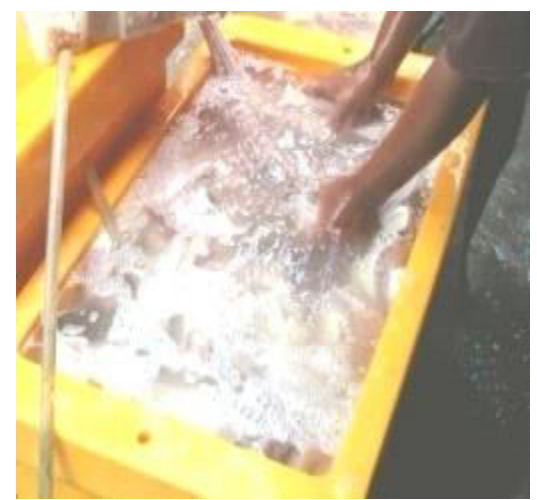

Gambar 3. Pencucian bahan baku

\section{Penirisan}

Ikan yang telah dicuci dilakukan penirisan untuk membuang air yang masih tersisa dalam potongan Ikan Pari dan mengurangi air setelah perlakuan pencucian agar proses pengasapan dilakukan mendapatkan kualitas yang bagus. Penirisan ini dilakukann selama \pm 15 menit atau sampai air sisa pencucian tidak menetes lagi. Adapun proses penirisan dilihat pada Gambar 4.

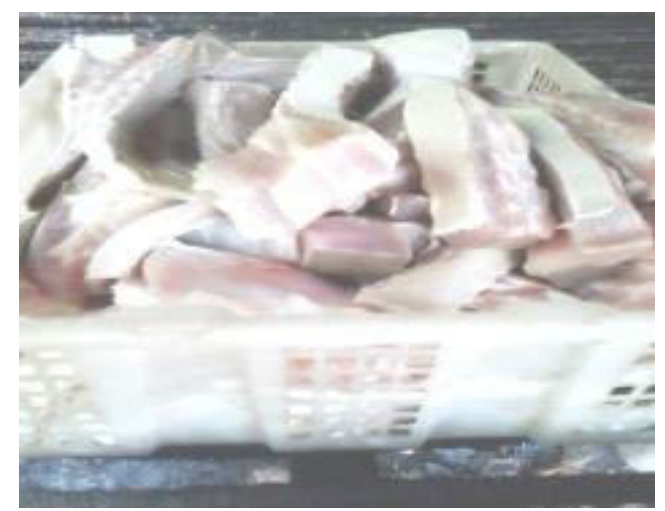

Gambar 4. Penirisan

\section{Penyusunan}

Penyusunan dilakukan secara teratur dengan posisi kulit dibagian atas dengan tujuan untuk menghasilkan penyerapan asap yang bagus agar ikan pari asap matang dengan bagus hingga menghasilkan warna yang khas pada pengasapan ikan. Proses penataan dapat dilihat pada Gambar 5

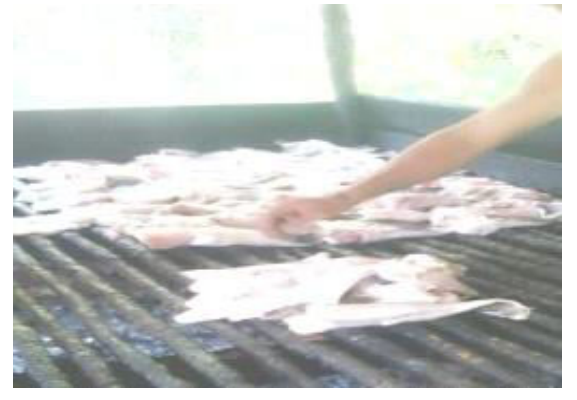

Gambar 5. Penyusunan

\section{Pengasapan}

Proses pengasapan yang dilakukan di Home Industry Nangahan Timor menggunakan pengasapan panas dengan suhu berkisar antara $120^{\circ} \mathrm{C}$ sampai $180^{\circ} \mathrm{C}$ selama 6 jam. Untuk mendapatkan hasil yang matang dan merata maka selama proses pengasapan ikan pari asap perlu dibolak-balik setelah 3 jam waktu pengasapan berlangsung. Saat proses pengasapan berlangsung asap selalu dikontrol agar api tidak menyala sehingga tidak menyebabkan hangus. Proses pengasapan terdapat pada Gambar 6.

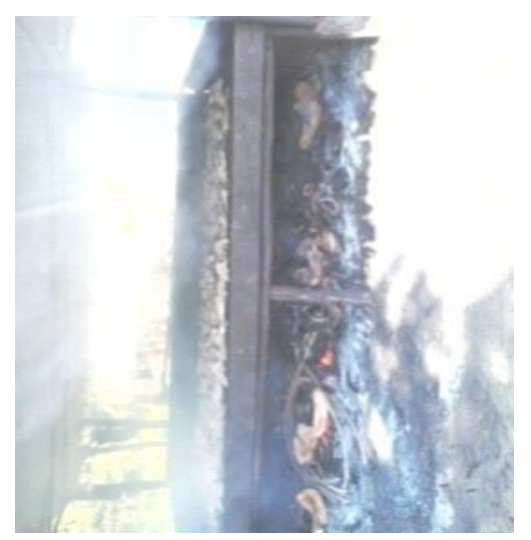

Gambar 6. Pengasapan Ikan Pari

\section{Pengemasan}

Sebelum dilakukan proses pengemasan terlebih dahulu ikan yang sudah dilakukan proses pengasapan kemudian didinginkan dalam suhu ruang. Setelah itu, ikan pari asap yang sudah dingin dimasukkan dalam keranjang plastik. Pengemasan ikan pari asap yang dilakukan di home industry/UKM ini sangat sedarhana yaitu hanya disimpan dalam wadah keranjang ketika proses peng-asapannya 
selesai, kemudian ikan pari asap ini siap untuk dipasarkan atau dijual.

\section{Perubahan Total bakteri (angka lempeng total/ALT) pada ikan pari asap dengan kemasan vakum}

Ikan Pari Asap setelah mengalami proses pengolahan, walaupun sudah melalui proses pemanasan tetap bisa mengalami proses kemunduran mutu. Proses kemunduran mutu ikan pari asap dapat disebabkan oleh berbagai reaksi mikrobiologis, kimiawi maupun fisik. Secara detail perubahan mikrobiologi berdasarkan uji Angka Lempeng Total (ALT) atau total bakteri pada penyimpanan ikan Pari asap dapat dilihat pada Tabel 1.

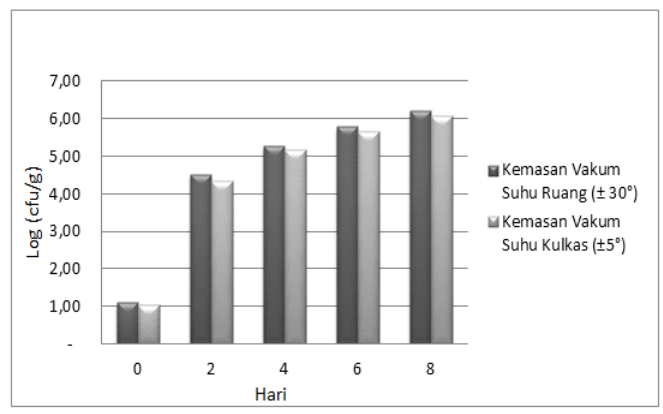

Tabel 1. Perubahan mikrobiologis (Total bakteri atau Angka Lempeng Total/ALT)

Perubahan jumlah bakteri ikan pari asap (Tabel 1), menujukkan kenaikkan jumlah total bakteri pada kedua perlakuan seiring bertambahnya waktu. Akan tetapi berdasarkan analisa statistik tidak berbeda nyata pada kedua perlakuan, baik hari ke0,2,4,6, maupun 8. Jumlah total bakteri atau Angka Lempeng Total (ALT) pada kemasan vakum pada suhu kamar $\left( \pm 30^{\circ} \mathrm{C}\right)$ terjadi kenaikan sedikit (tidak sampai 1 log cycle) dibandingkan dengan kemasan vakum pada suhu kulkas $\left( \pm 5^{\circ} \mathrm{C}\right)$. Berdasarkan hasil pengujian ALT yang dilakukan, ikan pari asap dalam kemasan vakum yang disimpan pada suhu kamar $\left( \pm 30^{\circ} \mathrm{C}\right)$ masih layak dikonsumsi dengan nilai ALT sebesar 1,9 x $10^{5} \mathrm{koloni} / \mathrm{g}$. Ikan pari asap dalam kemasan vakum pada kulkas $\left( \pm 5^{\circ} \mathrm{C}\right)$ masih layak juga untuk dikonsumsi sampai hari ke- 4 dengan nilai ALT sebesar $1,5 \times 10^{5}$ koloni/g. Sedangkan pada hari ke- 6 ikan pari asap dalam kemasan vakum yang disimpan pada suhu kamar $\left( \pm 30^{\circ} \mathrm{C}\right)$, sudah tidak layak dikonsumsi denga nilai ALT sebesar $6,1 \times 10^{5} \mathrm{koloni} / \mathrm{g}$. Ikan pari asap dalam kemasan vakum pada kulkas $\left( \pm 5^{\circ} \mathrm{C}\right)$ pada hari ke-6 sudah mulai tidak layak dikonsumsi dengan nilai ALT sebesar 5,4 x $10^{5} \mathrm{koloni} / \mathrm{g}$. Batas ambang ikan pari asap yang layak dikonsumsi berdasarkan batas ambang cemaran mikroba pada produk pangan (SNI 7388-2009).

Ikan pari asap pada kemasan vakum pada suhu kamar $\left( \pm 30^{\circ} \mathrm{C}\right)$ pada hari pertama (ke-0) terjadi kenaikan ALT sebesar 0,07 log cycle. Pada hari ke -2, terjadi kenaikan ALT sebesar 0,16 log cycle. Hari ke -4 , terjadi kenaikan ALT sebesar 0,10 log cycle. Hari ke -6, terjadi kenaikan ALT sebesar 0,12 log cycle.

\section{Perubahan aktifitas air bebas (aw) pada ikan pari asap dengan kemasan vakum}

Pertumbuhan bakteri pada ikan Pari asap, salah satunya dipengaruhi oleh aktivitas air (aW), karena bakteri menggunakan air bebas (aW) untuk pertumbuhannya. Perubahan aW pada ikan pari asap yang disimpan dalam kemasan vakum baik pada suhu suhu kamar $( \pm 30 \mathrm{C})$ maupunsuhu kulkas $( \pm$ 5C) dapat dilihat pada Tabel 2.

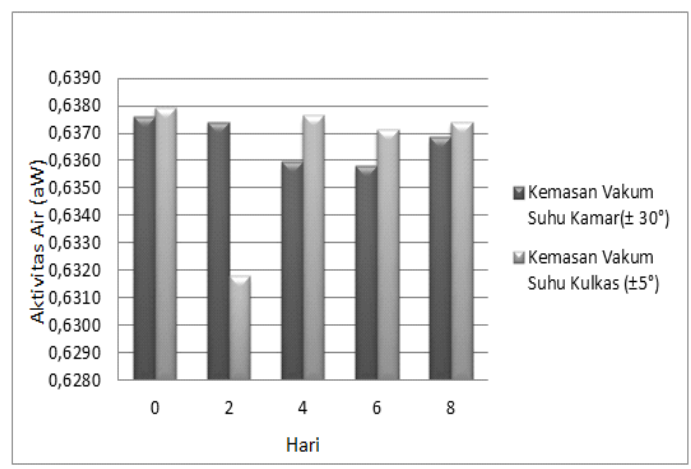

Tabel 2. Perubahan aktivitas air (aW) pada ikan pari asap

Ikan pari asap pada kemasan vakum pada suhu kamar $\left( \pm 30^{\circ} \mathrm{C}\right)$ pada hari pertama (ke-0) aW lebih rendah 
dibandingkan dengan penyimpanan pada suhu kulkas $( \pm 5 \mathrm{C})$, demikian pula pada hari ke- 4, 6 dan 8. Hal ini disebabkan karena plastik bersifat kedap udara, sehingga dapat mempertahankan kandungan air. Selain hal tersebut menurut Sulistijowati dkk (2011), kecepatan penguapan air pada pengasapan tergantung pada kapasitas pengering udara dan asap, juga kecepatan pengaliran asap. Pada tahap kedua, di mana permukaan ikan sudah agak kering, suhu ikan akan mendekati suhu udara dan asap. Kecepatan pengeringan akan menjadi lambat karena air harus merembes dahulu dari lapisan dalam daging ikan, bila pengeringan mula-mula dilakukan pada suhu yang terlalu tinggi dan terlalu cepat, maka permukaan ikan akan menjadi keras dan akan menghambat penguapan air selanjutnya dari lapisan dalam,sehingga kemungkinan daging ikan bagian dalam tidak mengalami efek pengeringan. Sehingga kandungan aW nya masih tinggi, hal ini memungkinkan untuk pertumbuhan mikroorganisme baik bakteri maupun jamur.

Secara umum diketahui bahwa peningkatan nilai aw cenderung mengurangi umur simpan produk tersebut. Hal ini berkaitan dengan jumlah air bebas (aW) dalam produk makanan yang dapat digunakan oleh organisme mikro seperti kapang, khamir dan bakteri untuk tumbuh, serta meningkatkan kemungkinan terjadinya reaksi kimia maupun enzimatik selama masa penyimpanan (Eskin dan Robinson, 2010).

Akan tetapi pada hari ke-2 aW ikan pari asap penyimpanan suhu kulkas $( \pm 5 \mathrm{C})$, mengalami penurunan aW yaitu dari hari ke0 sebesar 0,6380 hari ke -2 menjadi 0,6318. Ikan yang diolah dengan cara pengasapan dapat menjadi awet disebabkan oleh bebrapa faktor, di antaranya berkurangnya kadar air ikan sampel di bawah 40 persen (Sulistijowati dkk,2011).

Berdasarkan uji statistik, aW pada ikan pari asap yang disimpan dalam kemasan vakum baik pada suhu kamar $( \pm$ 30C) maupun suhu kulkas ( \pm 5C) tidak berbeda nyata.

\section{Perubahan derajat keasaman (pH) pada ikan pari asap dengan kemasan vakum}

Perubahan derajat keasaman ikan pari asap yang disimpan dalam kemasan vakum baik pada suhu suhu kamar $( \pm$ 30C) maupun suhu kulkas $( \pm 5 \mathrm{C})$ dapat dilihat pada Tabel 3.

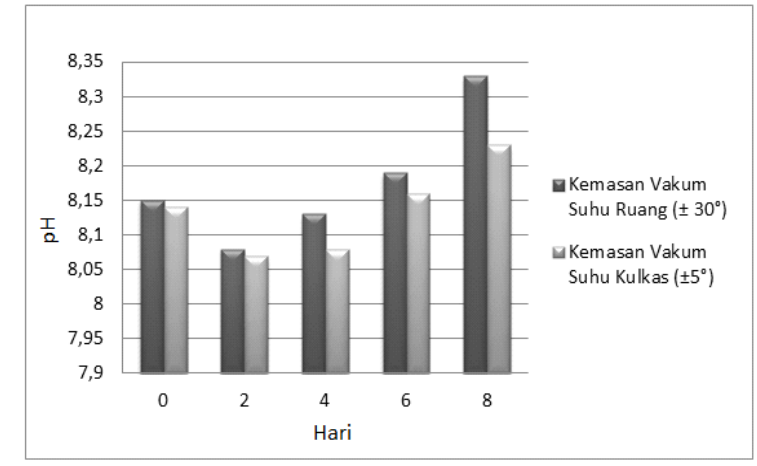

Tabel 3. Perubahan derajat keasaman $(\mathrm{pH})$ pada ikan pari asap

Tabel 3 menunjukkan derajat keasaman $(\mathrm{pH})$ pada kemasan vakum suhu kulkas $( \pm 5 \mathrm{C})$ lebih rendah dibandingkan dengan kemasan vakum suhu kamar $( \pm$ 30C). Kenaikan $\mathrm{pH}$ pada kemasan vakum suhu kamar $( \pm 30 \mathrm{C})$ disebabkan karena proses biokimia yang terjadi pada daging ikan pari asap. Menurut Fardiaz (1992), nilai derajat keasaman $(\mathrm{pH})$ merupakan salah satu indikator pengukuran tingkat kesegaran ikan. Pada proses pembusukan ikan, perubahan $\mathrm{pH}$ daging ikan disebabkan oleh proses autolisis dan penyerangan bakteri. Proses biokimia tersebut diiantaranya adalah terjadi penguraian oleh bakteri, sehingga semakin banyak bakteri yang ada pada ikan maka akan semakin banyak hasil metabolisme yang dihasilkan sehingga akan mempercepat proses pembusukkan.

Nilai $\mathrm{pH}$ terendah terjadi pada hari ke2 baik pada ikan pari asap kemasan vakum yang disimpan pada suhu kamar $( \pm 30 \mathrm{C})$, yaitu dengan $\mathrm{pH} 8,08$ maupun pada suhu kulkas $(( \pm 5 \mathrm{C})$ dengan $\mathrm{pH} 8,07$. Berdasarkan perhitungan statistik dari kedua perlakuan tersebut tidak menunjukkan beda nyata. Demikian pula pada hari ke- 4, 6 dan 8 terus mengalami kenaikan walaupun tidak 
signifikan. Hal ini terjadi karena $\mathrm{pH}$ pada ikan pari asap akan terus naik seiring dengan proses pembusukkan yang terjadi. Selama penyimpanan akibat degradasi protein menghasilkan sejumlah basa yang mudah menguap seperti amoniak, histamin, dan trimetilamin. Aksi enzimatik tidak tergantung oksigen, tetapi aksi enzim proteolitik tergantung pada temperatur. Aksi enzimatik menurun pada temperatur rendah. Kontrol aksi enzimatik dapat dilakukan dengan menurunkan temperatur, sedang efek sampingan dapat diatasi dengan pengepakan tahan air dan film impermeabel oksigen. Enzim menjadi tidak aktif pada pemanasan produk (Sulistijowati dkk, 2011)

\section{KESIMPULAN DAN SARAN}

\section{Kesimpulan}

Kesimpulan dari penelitian terapan ini antara lain:

1. Proses pengolahan ikan pari asap dimulai dari Penyiangan dan pemotongan, Pencucian, Penirisan, Penyusunan, Pengasapan dan Pengemasan.

2. Perubahan total bakteri (Angka Lempeng Total/ALT) pada ikan pari asap dengan kemasan vakum menunjukkan jumlah bakteri ikan pari asap mengalami peningkatan pada kedua perlakuan (baik yang disimpan pada suhu ruang $\left( \pm 30^{\circ} \mathrm{C}\right)$ maupun pada suhu kulkas $\left( \pm 5^{\circ} \mathrm{C}\right)$ ) seiring dengan bertambahnya waktu. Kemasan vakum yang disimpan pada suhu ruang sedikit lebih tinggi daripada yang disimpan pada suhu kulkas. Namun berdasarkan analisa statistik tidak berbeda nyata pada kedua perlakuan, baik hari ke- $0,2,4,6$, maupun 8 .

3. Perubahan aktifitas air bebas pada ikan pari asap dengan kemasan vakum menujukkan Ikan pari asap pada kemasan vakum pada suhu kamar $\left( \pm 30^{\circ} \mathrm{C}\right)$ pada hari pertama (ke-0) aW lebih rendah dibandingkan dengan penyimpanan pada suhu kulkas $( \pm 5 \mathrm{C})$, demikian pula pada hari ke- 4, 6 dan 8. Berdasarkan analisa statistik aW pada ikan pari asap yang disimpan dalam kemasan vakum baik pada suhu kamar $\left( \pm 30^{\circ} \mathrm{C}\right)$ maupun suhu kulkas $\left( \pm 5^{\circ} \mathrm{C}\right)$ tidak berbeda nyata.

4. Perubahan Derajat Keasaman $(\mathrm{pH})$ pada ikan pari asap dengan kemasan vakum menunjukkan derajat keasaman $(\mathrm{pH})$ pada kemasan vakum suhu kulkas $( \pm 5 \mathrm{C})$ lebih rendah dibandingkan dengan kemasan vakum suhu kamar $( \pm 30 \mathrm{C})$. Berdasarkan analisa statistik $\mathrm{pH}$ pada ikan pari asap yang disimpan dalam kemasan vakum baik pada suhu kamar $( \pm$ $30 \mathrm{C})$ maupun suhu kulkas $( \pm 5 \mathrm{C})$ tidak berbeda nyata. Demikian pula pada hari ke- 4, 6 dan 8 terus mengalami kenaikan walaupun tidak signifikan.

\section{Saran}

Adapun saran dari penelitian terapan ini antara lain:

1. Pengemasan akhir ikan pari asap dengan kemasan vakum merupakan salah satu cara pemecahan masalah untuk mengatasi rendahnya kualitas ikan pari asap.

2. Penyimpanan produk ikan pari asap dapat dilakukan dengan cara menyimpan produk dengan menggunakan suhu dingin maupun suhu ruangan namun untuk mendapatkan hasil pengawetan yang terbaik dapat dilakukan dengan penyimpanan dingin sehingga produk dapat menjadi lebih tahan lama.

\section{DAFTAR PUSTAKA}

Badan Standarisasi Nasional. (2006). Standar Nasional Indonesia (SNI 012346- 2006) Petunjuk Pengujian Organoleptik dan atau Sensori. Dewan Standarisasi Nasional - DSN, Jakarta

Eskin M dan Robinson D S. (2010). Food Shelf Life Stability, Chemical, Biochemical and Microbiological Changes. Taylor and Francis, USA

Fardiaz S. (1989). Petunjuk Praktikum Mikrobiologi Pangan. Direktorat Jend. Pend Tinggi. Dekdikbud. PAU-IPB. Bogor 
Kementrian Kelautan dan Perikanan. (2012).

Pusat Data Statistik dan Informasi

Sekretariat Jenderal Kementrian

Kelautan dan Perikanan. Jakarta

Kusnandar F. (2010). Memahami Aktivitas

Air dan Hubungannya dengan

Keawetan Pangan. IPB
Sulistijowati R, Djunaedi O S, Nurhajati J, Afrianto E, Udin. Z. (2011). Mekanisme Pengasapan Ikan. UNPAD PRESS Bandung 